\title{
The bakhtinian concepts of ideology and dialogue as input to promote the development of ideas in academic literacy processes
}

Fecha de recepción: 9 de febrero de 2016 Fecha de aprobación: 21 de abril de 2016 Pp. 7-26

\author{
Héctor Manuel Serna Dimas ${ }^{l}$ \\ Universidad EAN \\ hmserna@universidadean.edu.co Héctor
}

Cómo citar este artículo: Serna Dimas, H. M.. (2016). The Bakhtinian concepts of ideology and dialogue as input to promote the development of ideas in academic literacy processes. Comunicación, cultura y política, 7, pp 7-26.

\begin{abstract}
This theoretical essay works around the changing place of reading and writing, not only in the learning environments but in society. It brings into consideration the development of ideas as an extremely important resource when it comes to presenting reading and writing in these contexts. Such development can arise when Bakhtin's concepts around ideology (system of ideas) and dialogue become the guiding principles of any pedagogy that is interested in reading and writing processes.

This text addresses the different ideologies of the writing processes (traditional, cognitive expressivist, and socio-epistemic), and it concludes that the socio-epistemic posture expressed through the pedagogy of the writing genres responds better to the concepts of ideology and dialogue, being this one the most solvent to assume processes of reading and writing concerned with the development of ideas.
\end{abstract}

\section{Keywords}

Reading and writing, ideology, dialogue, cognitive expressivism, socio-epistemic.

\footnotetext{
${ }^{1}$ Doctorado en Philosophy in Composition and TESOL por la Indiana University of Pennsylvania. Magister en Arts in Teaching English as a Second Language por el Saint Michael's College. Lcenciado en idiomas por la universidad Nacional de Colombia. ORCID: http://orcid.org/0000-0002-6538-475X.
} 


\section{Los conceptos bakhtinianos de ideología y diálogo como insumo para promover el desarrollo de ideas en los procesos de alfabetización académica}

\section{Resumen}

Este ensayo téorico trabaja en torno al lugar cambiante de la lectura y la escritura, no solo en ambientes académicos sino en la sociedad. Pone en consideración al desarrollo de ideas como un recurso de suma importancia cuando se busca presentar la lectura y la escritura en estos contextos. Dicho desarrollo puede originarse cuando los conceptos de Bakhtin en torno a la ideología (sistema de ideas) y el diálogo se convierten en los principios rectores de cualquier pedagogía interesada en procesos de lectura y escritura. Se abordan en este texto las distintas ideologías de los procesos de escritura (tradicional, cognitiva expresivista y socio-epistémica) y se concluye que la postura socio-epistémica expresada a través de la pedagogía de los géneros de escritura responde más a los conceptos de ideología y diálogo, siendo esta la más solvente para asumir procesos de lectura y escritura preocupados por el desarrollo de ideas.

\section{Palabras clave}

Lectura y escritura, ideología, diálogo, expresivismo cognitivo, socio-epistémico.

\section{Notions bakhtinienne de l'idéologie et de dialogue le comme une contribution pour promouvoir le développement des idées dans les processus d'alphabétisation scolaire}

\section{Résumé}

Cet essai théorique porte sur les variations des modes de lecture et d'écriture dans un contexte académique et sociétal. La formation idéologique y est considérée comme un recours d'importance dans la présentation de la lecture et de l'écriture dans ces deux contextes. La formation des idées prend son origine lorsque les concepts de Bakhtin d'idéologie (système d'idées) et de dialogue se convertissent en principes directeurs des pédagogies s'intéressant aux processus de lecture et d'écriture.

Ce texte aborde les différentes idéologies des processus d'écriture (traditionnel, expressivocognitive, socio-epistémique) et conclut que la philosophie socio-epistémique exprimée au travers de la pédagogie des styles d'écriture répond davantage aux concepts d'idéologie et de dialogue, plus à même de développer les processus de lecture et d'écriture de la formation idéologique.

\section{Mots clés}

Lecture et écriture, idéologie, dialogue, expressivisme cognitif, socio-epistémique. 


\section{Noções bakhtinianas de ideologia e diálogo como contribuição para promover o desenvolvimento de ideias nos processos de alfabetização acadêmica}

\section{$\underline{\text { Resumo }}$}

Este ensaio teórico revisa o lugar mutável da leitura e escrita, não só nos círculos acadêmicos, mas na sociedade. Este trabalho considera o desenvolvimento de ideias como um recurso de extrema importância quando se busca introduzir a leitura e a escrita nestes contextos. Este desenvolvimento pode surgir quando os conceitos de Bakhtin ao redor da ideologia (sistema de ideias) e o diálogo tornam-se os princípios orientadores de qualquer pedagogia interessada em processos de leitura e escrita.

As diferentes ideologias dos processos de escrita (tradicional, cognitivista expressivista e sócio epistêmica) são abordadas neste texto e conclui-se que a posição sócia epistêmica expressa através do ensino de gêneros de escritura responde aos conceitos de ideologia e diálogo, sendo esta a mais efetiva para assumir processos de leitura e escrita preocupados com o desenvolvimento de ideias.

\section{Palavras-chave}

Leitura e escrita, ideologia, diálogo, expressivismo cognitivo, sócio epistêmico. 


\section{Introducción}

Desearch on writing is one of the most prolific fields in tertiary education 1 these days; this research has been the result of a number of problems that faculty and students encounter in university settings. Some of these problems have to do with the lack of abilities students seem to have to face the academic workload of professional programs. Some other times, the difficulties arise when there is a clear mismatch between the knowledge, the skills, or the competencies these people are developing in their university education and the demands of the workplace. It is no secret that some companies have established training programs for their new employees where workplace writing together with computation skills are some of the training areas.

There have been a number of studies on academic literacy in Latin America in which the focus has been to change the view that people have about literacy as isolated activities aimed at passing academic courses or completing degrees. In fact, there is a growing tendency towards a much more comprehensive view of writing across the curriculum and its real impact on the process of professionalization. Carlino (2005), for example, asserts that reading and writing practices at the university level are taken as academic practices that do not have a clear connection with the long-term education of professionals. In other words, undergraduate students use their writing as a purpose in itself without even thinking its proper place as part of their education in different fields of knowledge in either sciences or humanities.

In Colombia, several universities have been also working towards creating academic proposals whose foci are both the pedagogic and didactics of literacy in academic settings. There are also growing networks of professionals whose research interest is the place of literacy in the process of professional education. Nevertheless, most of the work in this area shows that academic literacy does not have a dominant place in the education of new professionals, and it is still viewed as a lesser process that belongs to the faculty in the humanities programs. As a result, universities still see reading and writing as isolated areas that professionals require, but sometimes they do not envision their impact or even their importance. 
In a research project on the nature of academic reading and writing in the Colombian university, Pérez and Rincón (2013) reported that the students they surveyed used their literacy skills to respond to the particular demands of their courses, which were for the most part geared towards either oral or written evaluations. The authors also reported on the type of written assignments students presented in their university courses; they claimed that many of them were opinion papers that they had built in their class notes, or materials that largely reflected the professors' input.

I think university faculty focus on the delivery of writing, but what is always problematic is to elucidate if students are articulating their ideas in writing. Faculty are correcting papers and wondering where the students are coming from or going to with their ideas. However, the emphasis is in correcting the formulation of those ideas to complete some sort of class project namely essay, research paper, or thesis, yet the origin of these ideas and its influence on students' intellectual development does not seem to receive much attention.

The purpose of this theoretical essay is to reinstate the place of literacy, not only in academic settings but also in society, by bringing to the surface one of the most important resources when academic settings attempt to introduce any literacy process: the development of ideas. There is certainly a need for individuals to make sense of themselves and their ideas regardless the area of work they belong to. Such sense making can take place as long as these individuals understand and assume writing as the most certain means to do so. The central thesis of the present essay has to do with the inclusion of the Bakhtinian concepts of ideology and dialogism (Bakhtin, 1981), as central tenets in the teaching of literacy processes that should aim at having students elucidate their positions about different aspects of their lives. In fact, Bakhtin's reflections about the discourse in the novel resonate with what may happen in literacy classrooms these days.

Pérez and Rincón reported in their research how students tried to replicate their professor's ideas for some sort of oral or written evaluation for their university courses. In a similar vein, Bakhtin (1981) warns about the risk of assuming somebody else's discourse in the sense of information, rules, and models as a clear sign of authoritative discourse becoming internally persuasive 
(p. 342). It is certainly a problem that individuals in academic settings may just assume their professors' perspectives without much examination, and worse without their own process of elaboration.

The paper begins by describing the place of literacy in current times, and the importance of writing as an asset in education. The paper, then, addresses the Bakhtinian concepts of ideological becoming and dialogism as guiding principles to reintroduce academic literacy in educational contexts. There is also a discussion about the relationship of rhetoric and ideology in particular research settings, and the connections between the two of them. The last part of the paper has to do with the views of faculty in terms of the ideologies of writing. I argue that the socio-literate perspective is more encompassed with the Bakhtinian concepts of ideological becoming and dialogism, which I consider should be taken into consideration by university faculty if they want to work with their students around their intellectual development. I also claim that genre-based pedagogy provides a framework so that writing instructors articulate an approach to literacy that considers the text, the writers' roles, and the context.

\section{Literacy education in a world of change}

T he furious pace of changes in the modes of production, and the responses of society to the very same changes have been causing deep impact on education. For example, virtual environments that may or may not belong to a recognized university, college or some sort of accredited institution, have superseded the idea of education being imparted in the premises of institutions. Moreover, people are part of transnational projects of education that allow them to attend courses in a European university with professors who may not be European and the class participants are living in distant places such as Africa, Asia, or South America.

Transnationalism is a phenomenon that occurs within people and the ways they relate across physical boundaries between countries. It has been instigated by the growing expansion of mass communication and technology 
that has permitted people to transform the way they relate among themselves in society across national country boundaries.

The Computer-mediated communication (CMC) has also contributed to this project of transnationalism since people are now able to build entire communities beyond the physical sense of a place. In fact, these encounters do not necessarily require face-to-face interactions. In sum, we are witnessing a change from what Gee (2004) defined as "old capitalism" to the "new capitalism" (p. 279). On the one hand, he describes the old capitalism as the encounters of bosses and workers at the workplace where the former had to determine how the work had to be carried out, and the latter had to execute these ideas with precision. On the other hand, the new capitalism is not about the duties that managers and workers have with a company. It is mainly about the creation and sustainability of competent teams who are for the most part collaborating to help companies sustain their business in a fast changing business world. Gee adds that, in this new capitalism, jobs are defined in terms of projects where people are called upon to participate based on what he calls a "portfolio" (p. 284); that is, a comprehensive summary of people's qualifications, experiences, and competencies that showcase what these people employ to claim their legitimacy to be part of these teams and projects.

The new roles that workers perform in the corporate world and in society at large create new demands for educational institutions on the way they educate these new breeds of professionals. Gee asserts that schooling also needs to be renewed so that the idea of portfolio becomes more complex as people are always shifting not only their activities at work but also their self-conceptions. These changing portfolio or "shape-shifting portfolio" (p. 296) is developed through people's life experiences that are not exclusive to individuals since many of them happen as people are always in relation; they belong to likeminded groups, networks, professional communities, interest groups, and the like (Gee, 2004).

Literacy practices, as some of the most fundamental components of schooling, cannot escape this new reality. In fact, many of these portfolios will be based upon literacy products where students will make sense of those experiences and competencies by voicing them. This voicing may take a diversity of forms, and even the means of communication may be miscellaneous 
in nature. The above situation calls for teachers to broaden the scope of their conceptions of literacy beyond traditional classroom exercises around reading comprehension and writing activities. Mahiri (2004) departs from a definition of text as "any segment of language or symbol that creates a unit of meaning" (p.225). These units of meaning may range from essays, books, and stories to oral representations in terms of stories, and speeches. He also talks about representations in terms of dramatizations, films, and television, and even visual representations such as paintings, cartoons, sculpture, graphics, and holography (p. 224). Mahiri adds that this variety of texts give people more opportunities to voice their experiences not only in terms of narratives or stories but complex devices in which there is "an interdependence of meaning, texts, and history" (Mahiri, 2004, p. 225).

\section{Introducing the notions of ideology and dialogism in literacy settings}

These new circumstances in which people are coming together in both
physical and virtual worlds through a myriad of technological resources make it necessary to introduce the Bakhtinian concept of "ideological becoming" (p. 5), which in the words of Freedman and Ball (2004) means to educate individuals around the concept of the creation of idea systems. The scholars clarify the notion of ideology, which often times seems to be loaded with political ideas; however, they assert that the Bakhtinian concept is meant to develop one's own worldview. They insist that the concept is not intended to have the political connotations, yet it does not exclude such possibility, especially these days when politicians live off either the lack of ideas or the excess of radical thoughts or even the fanaticism of people. In sum, this ideological becoming has to do with how an individual grows as a person in society through the active exercise of his ideas in a variety of contexts.

The ideological becoming of an individual has a suitable setting in literacy classrooms where instructors also need to appropriate the concept of dialogism, which means that what happens in classrooms has to be around the dialogue 
among teachers and students. Nevertheless, this dialogue requires some conditions that they both need to fulfill. On the one hand, teachers need to be aware of the difficulty that students may have to articulate their ideas, especially if such an activity may be beyond the boundaries of the disciplines these teachers may have. I think that, at first, it is not so important to see where these ideas come from; what I consider essential is that there are ideas so that teachers see that there will be a system to build on. However, there has to be moments to explain and evaluate critically the origin and development of these ideas.

Seung Hui Cho committed a mass murder in Virginia Tech on April 16, 2007. He could have been another serial killer in the long history of shootings and killers in the United States. However, the investigation results showed that paying close attention to Cho's ideas in writing could have averted his destructive behavior. In fact, the day of the shooting, he released a manifesto (a written piece) whose meaning is the public declaration of intentions or purposes. In this manifesto, Cho expressed his views on what he considered the transgressions of life in college.

A professor or a student may make a racial or ethnic slur. I think these people have ideas that operate systematically for a number of reasons. I do not consider people are born racist, liberal, or conservative; they have been fed such belief systems by different people and institutions throughout their lives; however, they have not had the chance to challenge them with seriousness, or at least the opportunity to listen to the other side. Thus, the discussion of these ideas needs to be an important part of any classroom agenda no matter if this happens in a literacy course or not.

On the other hand, students need to be for the most part encouraged to understand that the development of an ideology as an idea system is fundamental for their development as scholars at any level of their scholarship namely primary, secondary, and tertiary school. Furthermore, this realm of ideas will not be exclusive to be educated; they are also the core for the development of people's citizenship.

There is another condition that involves both teachers and students, and it is motivated by the relations of authority and obedience that are present in classrooms where the teachers act from the perspective of the power vested 
in them to fulfill their roles of educators and experts. Students act from the perspective of submission by virtue of their roles as subjects in need of an education. These roles tend to be mistaken when teachers are authoritarians and students are either excessively submissive or resistant. Freedman and Ball (2004) cite the work of Bakhtin in regards to this particular conflict between "authoritative discourse" and "internally persuasive discourse" (p. 7); the former in terms of the discourse that has been built as part of ideologies (idea systems) which may come from a range of sources, the latter is the discourse based on conjectures or opinions. Morson provides an illustration of how a variety of authoritative discourses in today's world, such as the ones about diversity, impact a society like the North American; he sustains that:

Classrooms are more varied than ever before, with students coming together across what used to be considered uncrossable linguistic and cultural divides. These diverse populations bring a range of internally persuasive discourses, which will impact the process of ideological development and ideological development of all students inside our classrooms. They ensure plentiful tensions among a range of authoritative discourses to which different students will orient, and among a wide range of internally persuasive discourses as well (Morson, 2004, p. 8).

The dialogic process proposed by Bakhtin and his followers is not free from tension or discomfort since it imposes on people an honest effort to listen to the other and be sympathetic with his ideas. We can think of the almighty university professor whose students are just budding professionals or experts in his field of knowledge, or groups of students who may share the same country of origin, religion, and language and who happen to have new immigrants as their classmates. We might as well think of people who dream of living and working in multicultural and multilingual societies. 


\section{Literacy research on the concepts of ideology and dialogism}

Treedman and Ball report on their research on language literacy learning 1 that taps into working with the ideas of both ideological becoming and the voicing of people's points of view through dialogic exercises in educational settings. Ball developed her research in the United States and South Africa; these countries have diverse and multicultural populations where issues of power and marginalization are common currency due to unresolved racial tensions that seem to be aggravated these days. Freedman's research was conducted in Rwanda and Boznia-Herzegovina; these two countries were torn apart by internal war conflicts and genocides that caused both physical and psychological pain to their populations. There are numerous accounts of the killings of Tutsis in the hands of Hutus. In the same way, the world was in shock when they learned about the horrors of massacres and concentration camps that occurred in the confrontation among Serbs, Croats, and Bosnians.

Freedman's research in both contexts had to do precisely with how different stakeholders dealt with the hardships of wars and their post conflicts where authoritative discourses interacted with internally persuasive discourses. The former trying to promote a new state of affairs for these countries, and the latter witnessing the struggles that people had to go through to deal with these new living circumstances.

A similar conflict has been recorded for the last sixty years in Colombia where the government has fought the leftist guerrillas amid other bloody conflicts such as the right-wing paramilitarism, and the drug trafficking cartels. This internal war has had the disheartening toll of 220,000 deaths according to the National Center for the Historic Memory. Even though it is a problem to separate the condition of these casualties because they were all Colombian, it is striking to see that $81 \%$ of the victims were unarmed civilians and $19 \%$ were combatants (Centro Nacional de Memoria Histórica, 2016).

Colombia is in the process of ending this conflict by witnessing a ceasefire and the completion of an agreement, which aims at opening the opportunities for former guerrilla combatants to be fully integrated into society. However, the 
peace process and the conditions under which the guerrilla left their arms have created tension between two camps whose ideologies are even jeopardizing the end of the conflict process. These ideologies are closely related to particular rhetorics, which are by no means void of political intentions. On one hand, Colombians receive authoritative discourses from the leaders of both left and right parties. On the other hand, there is also the internally persuasive discourse of people who have lost a loved one or have had to live with an amputee, a victim of rape, kidnapping, forced displacement, or torture caused by the sides in conflict. There are also internally persuasive discourses of corrupt people who have profited from the conflict by providing weapons and other resources to either the military, the paramilitary, the guerrillas or sometimes all.

A discussion of rhetoric is important here since we may view it from a historical perspective beginning with Plato and Aristotle who debated the notion of rhetoric as the use of words to either persuade or deceive people. The notion has evolved and, in contemporary times, rhetoric has come to mean how to use the language to make sense of ourselves in complex societies. Moreover, Lindemann (2001) asserts that "rhetoric is viewed as an instrument of social change" (p. 53), and adds that the work of rhetoricians is to explore the relationships of language with other fields such as politics, anthropology, sociology, and of course the quintessential linguistics.

The above discussion of rhetoric and the current political situation in Colombia provides a thought-provoking setting for rethinking literacy practices at different levels of education, especially at the university level where students need to be educated on the self-construction of idea systems through literacy practices that precisely foster such construction. Morson asserts that such schooling has to always validate the idea of inner development where

The mind would be populated with a complexity of voices and perspectives it had not known, and the student would learn to think with those voices, to test ideas and experiences against them, and to shape convictions that are innerly persuasive in response. (Morson, 2004, p. 330). 


\section{The ideologies of writing}

Teachers who have become writing instructors, tutors, or lecturers in

1 reading and writing perform their roles based on their ideas on what good readers and writers do in and out of their courses. Many times their ideas also come from perspectives that they have developed as part of their scholarship as readers and writers. Johns (1997) describes three perspectives on literacy development, which seem to have different foci. The first view she presents is the traditional one, the second is the cognitive self-expressivist, and the last one is the socio-epistemic.

Traditional views of literacy date back from the 1960s and 1970s when positivistic orientations towards science took precedence, and the linguistic research was very focused on the dissection of texts in terms of grammatical or semantic features. Johns describes these classrooms to be teacher-centered and the focus was the study of vocabulary and grammar. Thus, the belief systems of teachers were that students' writing had to be flawless, and the products they had to write had to be error-free.

The traditional views of writing and writers were criticized from a number of camps, and the criticisms were about the disregard for the roles of readers and writers in the writing process, and how much they had to say about their ideas. A movement that appeared in the 1980s and whose focus was the learner provided a new rationale for literacy. This learner-centered movement argued for the purposeful inclusion of students' points of view in their writing. In fact, they claimed that successful literacy was the result of students' engagement with their ideas.

The cognitive self-expressivist movement of literacy promoted ideas that were precisely related to cognitive aspects such as schemata, text processing, and writing strategies. Literacy practices were led following the above elements; as a result, writing practices included a number of processes such as planning, prewriting, drafting, revising, and editing. In regard to strategies, students were encouraged to think of their writing as a strategic process where collaboration with peers and even with instructors was welcomed. 
The self-expressivist movement was not either free from criticism since people started considering that writing in certain contexts was not particularly free. For example, academic and workplace environments have specific demands that writers need to fulfill in order to become acting members of such communities. The above situation brought forth what is known as the socioliterate perspective of writing. The basic tenet of such an approach considers that writers are able to be part of discourse communities as long as they are introduced and mentored into the discourses of various social contexts. They do so by having exposure to texts, and more importantly to the circumstances that motivated writers to write such texts. Johns (1997) characterizes this view by asserting that, "students are constantly involved in research into texts, roles, and contexts and into strategies that they employ in completing literacy tasks within specific situations" (p. 15).

\section{Genre-based pedagogy}

Derhaps the literacy perspective that best encompasses the social literacy 1 approach to literacy is the genre-based pedagogy. Genre has been a central element of study from the areas of Systemic Functional Linguistics, the New Rhetoric, and English for Specific Purposes. Hyland (2004) offers a comprehensive account of these views of genre and its scope. For the Systemic theorists, genres "are characterized by rhetorical patterns such as narratives, recounts, arguments and expositions" (p. 28). This view focuses on the social purposes of discourse. The New Rhetoric argues for a view of genre beyond the linguistic framework; a perspective that takes into consideration "ideological and social perspectives derived from cultural and rhetorical studies and only occasionally from detailed analyses of texts" (Hyland, 2004, p. 36). The English for Specific Purposes (ESP) perspective looks at how genre "can be a tool for understanding and teaching the kinds of writing required by non-native English speakers in academic and professional settings" (Hyland, 2004, p. 43).

These different views of genre provide perspectives towards literacy. I do not think these views are meant to be exclusive; they all have elements that constitute what scholars have theorized as 'genre knowledge'. This knowledge is played out as it touches on aspects such as the cognitive, communicative, 
textual, and intertextual dimensions of literacy. Recognizing a text as a member of a particular genre shows that readers make use of a network of relations built from previous encounters with the print world. These networks are known as schemata, and what the situation suggests is that people engage in cognitive activities using knowledge that relates what they already know with the new experiences.

The communicative dimension of genre has to do with the purposes people want to achieve as they produce texts. Hyland (2004) claims that the definition of most genres is based on the communicative purposes they are to achieve. Perhaps one of the most common aspects of genre studies is the definition of social purpose of texts, since there is not a clear-cut means of identifying types of texts.

Genre knowledge places a special emphasis on text conventions. The membership of texts in a particular genre is connected with a set of conventions, vocabulary, grammar, content and organization. Genre critics consider the reduction of texts as sets of conventions a problem; nevertheless, these aspects also show the mobility of genre since the boundaries of genre also show the possibilities of both their relationships and their scope.

Intertextuality is probably one of the most fascinating aspects of genrebased pedagogy. It refers to the web of connections that can be established among texts. Texts have the possibility to exist in the present, but their origins have elements in the past, and they can also have an impact in the future. Intertextuality makes possible to "link writers, readers, and meaning together" (p.80).

In sum, genre-based teaching integrates elements from society, the learner, and the text as language, which is used with a purpose in order to achieve particular communicative goals through constant processes of meaning negotiation. This view of literacy is also gaining momentum in L2 writing instruction, since the teaching of writing has been seen as a component of the communicative abilities in language. However, this aspect is not addressed in the L2 classroom because many of the goals in language learning are more oriented towards listening and speaking. 
The above description of the shared aspects of genre poses a challenge to people in either academic or workplace settings. The nature of texts require from writers to comply with all the aspects that make a text to be recognized as legitimate in a particular discourse community. Writing, then, is about creating a text with some specific conventions or stylistic features that match a particular communicative purpose, and whose success will be based on how the writer integrates the above elements. If we think of the university setting, students are faced with the challenge of writing a number of texts that allow them to be part of the university and its discourse community. Some of these texts are critical reviews, essays, and research papers.

Bartholomae (1986) writes about the university setting, and how much understanding of the students who are enrolled in its programs is required, and how responsive these students may be to particular needs in order to comply with their work in academia. Bartholomae talks about how much students need to be introduced to the discourses of academia and master them. He feels that students need to be encouraged to have authority over what they think and write so that their writing progresses towards the discourse community of academia.

I think that Bartolomae's ideas about students developing their authority over their ideas match the idea of working with students to develop their ideologies or idea systems. These idea systems will appear when these students are encouraged to voice their ideas and structure them so that they become authoritative of their own thoughts; this process will be hastened through writing courses relied on a solid genre-based pedagogy that brings together the text, the writers, and the contexts of writing. To sum up, literacy processes should include the above elements; however, they will only account for students' development as writers as long as such instruction takes place following the concepts of ideological becoming and dialogism. I strongly believe that literacy instructors, at any level, should make of these ideas their own ideologies or philosophies, and I want to take the noblest idea of philosophy regarding it as rigorous thinking.

My proposal for this view of literacy has both dialogism and ideologies gravitating around texts, which are for the most part the result of the articulation among the writers, the context, and the actual text production. 
The above elements are enacted through genre-based pedagogy in which writers are exposed to texts and are also allowed to study them so that they see what writing communities have established as their purposes and conventions of writing.

A practical view of this proposal in a writing classroom would start by eliciting students' previous knowledge about a topic such as racism. Once students present their views, they will be confronted with a number of questions that are meant to explore their own construction of such views on racism, and to establish a dialogue around this issue. Then students will read assorted essays on aspects related to racism; they will be asked to find the theses of the essays and track their development throughout the papers. Next, they will be asked to establish how the authors develop their arguments and the sources they use to validate their theses. After that, they will revise their own views on racism and determine how they have created these perspectives. At this point, it is important that students are willing to discuss their views through a dialogic exercise in order to see if their ideas have some sort of development or evolution. Finally, they will be asked to write an essay on the same issue of racism; however, this particular assignment has already disclosed the criteria they need to have in mind in order to substantiate their claims.

Figure 1. Rethinking literacy

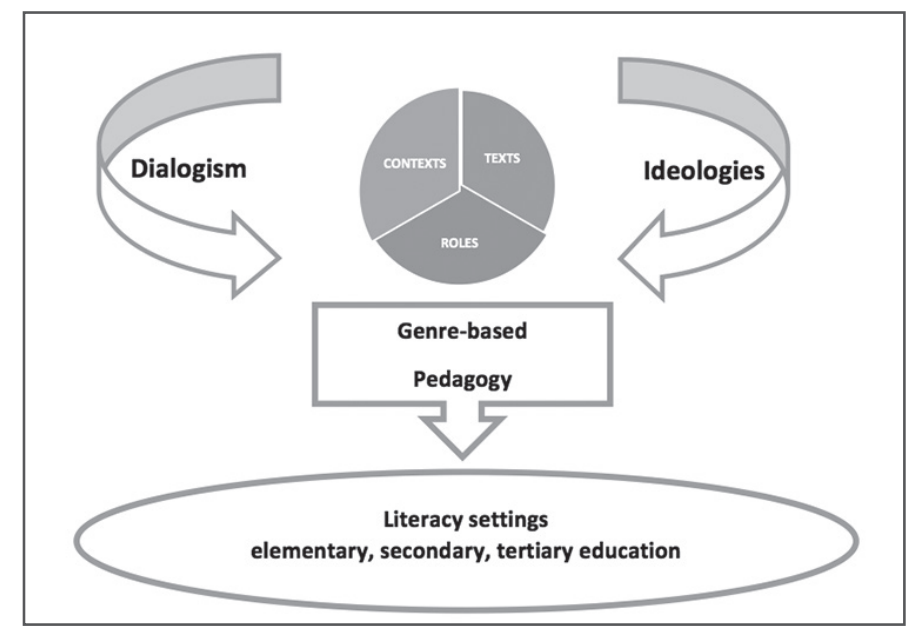

Source. Own elaboration 


\section{Conclusions}

Tbegan this paper by indicating the importance of literacy practices as moments in which people can actually see the development of their ideas. I also pointed out that literacy instructors do not pay that much attention to such development when students present their papers, because these written productions are considered requirements to complete a course or a degree. In fact, seldom do these writers go back to these texts that allegedly made an important part of either their professionalization or education.

I argued for reintroducing literacy using as pivotal elements the Bakhtinian concepts of ideology and dialogism so that the practices around reading and writing actually make sense since they impose on people the need to become articulate and responsible for their ideas. Then, I discussed briefly the relationship between ideology and rhetoric in the research carried out by Freedman and Ball, which proved very relevant for the present circumstances of a country like Colombia. Next, I devoted a section of this paper to the ideologies of writing that are not intended to be exclusionary; however, the socio-epistemic views seem to be more in tune with the concepts of ideology and dialogism since writers produce texts based largely upon their roles and the demands of particular contexts. Finally, I made a brief description of genrebased pedagogy and its connections with the type of work that university students are required to do in their literacy practices. I want to end this article by quoting Bartolomae's insightful words about the academic work of university students, and the demands that it imposes on both professors and students:

Every time a student sits down to write for us, he has to invent the university for the occasion - invent the university, that is, or a branch of it, like History or Anthropology or Economics or English. He has to learn to speak our language, to speak as we do, to try on the peculiar ways of knowing, selecting, evaluating, reporting, concluding, and arguing that define the discourse of our community. Or perhaps I should say the various discourses of our community, since it is in the nature of a liberal arts education that a student, after the first year or two, must learn to try on a variety of voices and interpretive schemes - to write, for example, as a literary critic one day and an experimental psychologist the next, to work within fields where the rules governing the presentation of examples or the development of an argument are both distinct and, even to a professional, mysterious (Bartolomae, 1986, p. 4). 


\section{References}

Bakhtin, M. M. (1981). Discourse in the novel. In M. Holquist (Ed.), The dialogic imagination: Four essays by M.M. Bakhtin (C. Emerson, \& M. Holquist, Trans.). Austin, TX: University of Texas Press.

Bartholomae, D. (1986). Inventing the University. Journal of Basic Writing. $5,1, p .4-23$.

Carlino, P. (2005). Escribir, leer y aprender en la universidad. Una introducción a la alfabetización académica. Buenos Aires: Fondo de Cultura Económica.

Centro Nacional de Memoria Histórica. (2016, February 25). Retrieved from http://www.centrodememoriahistorica.gov.co/

Freedman, S. W., \& Ball,A. F. (Eds.). (2004). Ideological Becoming: Bakhtinian concepts to guide the study of language, literacy, and learning. In A. F. Ball \& S. W. Freedman (Eds.), Bakhtinian perspectives on language, literacy, and learning, 3-33. New York: Cambridge University Press.

Gee, J. P. (2004). New Times and New Literacies: Themes for a changing world. In A. F. Ball \& S. W. Freedman (Eds.), Bakhtinian perspectives on language, literacy, and learning. New York: Cambridge University Press.

Hyland, K. (2004). Genre and Second Language Writing. In D. Belcher \& J. Liu (Eds.), Michigan Series on Teaching Multilingual Writers. Ann Arbor, MI: The University of Michigan Press.

Johns, A. (1997). Text, role and context: Developing academic literacies. In M. H. Long \& J. C. Richards (Eds.). Cambridge: Cambridge Applied Linguistics.

Lindemann, E. (2001). A Rhetoric for Writing Teachers (4th Ed.). Oxford: Oxford University Press. 
Mahiri, J. (2004). New Teachers for New Times: The Dialogical Principle in Teaching and Learning Electronically. In A. F. Ball \& S. W. Freedman (Eds.), Bakhtinian perspectives on language, literacy, and learning, p.213231. New York: Cambridge University Press.

Morson, G. S. (2004). The process of ideological becoming. In A. F. Ball \& S. W. Freedman (Eds.), Bakhtinian perspectives on language, literacy, and learning, p. 317-331. New York: Cambridge University Press.

Pérez, M., \& Rincón, G. (2013). ¿Para qué se lee y se escribe en la universidad colombiana? Un aporte a la consolidación de la cultura académica del país (1ra ed.). Bogotá: Editorial Pontificia Universidad Javeriana. 